\title{
KAJIAN BENTUK-BENTUK EKSPLOITASI SEKS KOMERSIAL ANAK DI LINGKUNGAN WISATA PROVINSI SULAWESI UTARA
}

\author{
Rahmat Hidayat \\ Sekolah Tinggi Ilmu Sosial dan Ilmu Politik Merdeka, Manado \\ E-mail: rahma.hidayat74@yahoo.com
}

\begin{abstract}
ABSTRAK. Penelitian ini dilatarbelakangi oleh makin maraknya bentuk-bentuk Eksploitasi Seks Komersial Anak di Lingkungan Wisata Provinsi Sulawesi Utara, Pelacuran adalah bentuk Eksploitasi Seks Komersial Anak yang paling marak di wilayah ini, akan tetapi perangkat hukum ini kapasitasnya belum memadai untuk memberantas kasus kekerasan terhadap anak di Indonesia khususnya di Kota Manado Provinsi Sulawesi Utara. Pemerintah Provinsi Sulawesi Utara telah menyelenggarakan kegiatan sosialisasi Pengembangan Model Perlindungan Anak di Manado Sulawesi Utara, akan tetapi program tersebut belum mampu menjadi solusi tepat dalam mengeliminir kasus kekerasan seksual anak. Oleh karena itu, Kajian ini bertujuan untuk menganalisis bentuk-bentuk eksploitasi seksual komersial anak di lingkungan Wisata Provinsi Sulawesi Utara. Penentuan sampel bagi informan dilakukan secara Opportunistik Sampling dan Snowball Sampling. Hasil penelitian menunjukkan bahwa bentuk-bentuk Eksploitasi Seks Komersial Anak di Lingkungan Wisata Provinsi Sulawesi Utara adalah: Prostitusi anak, Pornografi dan Porno aksi, perdagangan anak untuk tujuan prostitusi, dan Transformasi budaya dan agama.
\end{abstract}

Kata Kunci: Bentuk- Bentuk Eksploitasi Seks Komersial Anak

\section{ASSESSMENT FORMS OF COMMERCIAL SEXUAL EXPLOITATION OF CHILDREN IN NORTH SULAWESI TOURISM ENVIRONMENT}

\begin{abstract}
This research is motivated by the increasing proliferation of forms of Child Commercial Sexual Exploitation in Tourism Environment North Sulawesi, prostitution is a form of Child Commercial Sex Exploitation of the most prevalent in this region, but the laws were not adequate capacity to tackle cases of violence against children in Indonesia particularly in the city of Manado North Sulawesi. North Sulawesi Provincial Government has organized dissemination activities Development Model for Child Protection in Manado North Sulawesi, but the program has not been able to be the right solution in the elimination of child sexual assault cases. Therefore, this study aimed to analyze the forms of commercial sexual exploitation of children in the province of North Sulawesi Tourism. Determination of sample for opportunistic informer done Sampling and Snowball Sampling. Hasil research shows that form-the form of Child Commercial Sexual Exploitation in Tourism Environment North Sulawesi are: Prostitution of children, Pornography and Porno action, child trafficking for purposes of prostitution, and the transformation of culture and religion.
\end{abstract}

\section{Keywords: Forms of Child Commercial Sex Exploitation}

\section{PENDAHULUAN}

Kota Manado Provinsi Sulawesi Utara merupakan salah satu kota wisata di Indonesia yang mengakibatkan semakin terbukanya akses untuk terjadinya eksploitasi seks komersial Anak. Pelacuran anak adalah bentuk eksploitasi seks komersial anak yang paling banyak di Manado, (Erwin,2011).

Indonesia telah mempunyai perangkat hukum untuk melindungi anak, antara lain Keppres RI No.87/2002 (RAN Penanggulangan ESKA), Kepres RI No. 88/2002 (RAN Penghapusan Perdagangan Perempuan Dan Anak), disahkannya UU No. 23/2002 Tentang Perlindungan Anak, Undang-Undang Kepariwisataan Nomor 9 Tahun 1990, yang dengan tegas menolak segala bentuk perjudian dan perzinahan (wisata seks), Dan UU Nomor 21 tahun 2007 tentang tindak pidana perdagangan orang yang ditindaklanjuti dengan penerbitan Perda di tingkat Kota Manado. Akan tetapi perangkat hukum ini kapasitasnya belum memadai untuk memberantas kasus kekerasan terhadap anak di Indonesia khususnya di Kota Manado Provinsi Sulawesi Utara.

Pemerintah Provinsi Sulawesi Utara telah menyelenggarakan kegiatan sosialisasi Pengembangan Model
Perlindungan Anak di Manado Sulawesi Utara, akan tetapi program tersebut belum mampu menjadi solusi tepat dalam mengeliminasi kasus kekerasan seksual anak. Peneliti pernah melakukan berbagai kajian akademik sehubungan dengan kekerasan seksual anak, namun hasilnya belum mampu menjadi solusi terbaik bagi pengentasan kasus kekerasan seksual anak, sehingga diperlukan kajian akademik yang mendalam dan komprehensif terkait dengan penanggulangan eksploitasi seks komersial Anak berbasis child right programming di lingkungan wisata Provinsi Sulawesi Utara. Berdasarkan hal tersebut, penelitian akan berupaya mengkaji tentang bentuk-bentuk Eksploitasi Seks Komersial Anak di Lingkungan Wisata Provinsi Sulawesi Utara.

\section{Konsep Eksploitasi Seksual Komersial Anak}

Kepres Nomor 87/2002 mendefenisikan ESKA, sebagai berikut: "Kekerasan Seksual oleh orang dewasa dan pemberian imbalan dalam bentuk uang tunai atau barang terhadap anak, atau orang ketiga, atau orang-orang lainnya. Selanjutnya ditegaskan bahwa Eksploitasi Seksual Komersial Anak adalah sebuah proses dimana anak diperlakukan sebagai sebuah objek seksual dan sebagai objek komersial, dan merupakan sebuah bentuk pemaksaan dan kekerasan terhadap anak 
serta mengarah pada bentuk-bentuk kerja paksa atau perbudakan modern." (Kepres Nomor 87/2002).

Eksploitasi Seks Komersial Anak sebagai sebuah pelanggaran mendasar terhadap hak-hak anak.Pelanggaran tersebut terdiri dari kekerasan seksual oleh orang dewasa dan pemberian imbalan dalam bentuk uang tunai atau barang terhadap anak, atau orang ketiga, atau orang-orang lainnya.Anak tersebut diperlakukan sebagai objek seksual dan sebagai objek komersial.Eksploitasi seksual komersial anak merupakan sebuah bentuk pemaksaan dan kekerasan terhadap anak dan mengarah pada bentuk-bentuk kerja paksa serta perbudakan modern. Dari definisi tersebut, jelas bahwa melalui eksploitasi seksual komersial anak, seorang anak tidak hanya menjadi sebuah obyek seks tetapi juga sebagai sebuah komoditas yang membuatnya berbeda dalam rehabilitasi maupun pemulihannnya serta reintegrasi dengan keluarga atau masyarakat.

ESKA adalah singkatan dari Eksploitasi Seksual Komersial Anak.Menurut Erwin dalam bukunya yang bertopikEksploitasiSeks KomersialAnak,mendefinisikan ESKA sebagai sebuah pelanggaran mendasar terhadap hak-hak anak.Pelanggaran tersebut berupa kekerasan seksual oleh orang dewasa dengan pemberian imbalan kepada anak, atau orang ketiga, atau orang-orang lainnya. Sederhananya anak diperlakukan sebagai objek seksual dan komersial.Ini adalah perwujudan dari kerja paksa dan perbudakan modern terhadap anak.Sebab tak jarang anakanak dipaksa, mengalami kekerasan fisik dan trauma (Erwin, 2011). Bentuk Eksploitasi Seksual Komersial Anak bermacam-macam dan masing-masing bentuk tersebut memiliki dampak merusak yang sama terhadap anak-anak dan masyarakat dimana ESKA tersebut terjadi. Bentuk-bentuk utama ESKA adalah pelacuran anak, pornografi anak, dan perdagangan anak untuk tujuan seksual.

Salah satu bentuk Eksploitasi Seksual Komersial Anak yang telah mendapat perhatian besar dari media dan masyarakat selama 15 tahun terakhir ini ada di lingkungan wisata.Pariwisata Seks Anak kadangkadang mengacu pada eksploitasi seksual anak dalam pariwisata. Pariwisata seks anak terjadi di berbagai tujuan wisata dan bahkan di tempat-tempat yang sebenarnya tidak memiliki prasarana pariwisata sama sekali (Erwin, 2011).

\section{Pendekatan Pembangunan Berbasis Hak Anak (Child Right Programming).}

Pendekatan pembangunan berbasis hak anak atau dikenal dengan child right programming adalah sebuah pendekatan pembangunan berbasis hak (right based approach) dengan menempatkan anak sebagai pusat dari seluruh aktivitas dalam pembangunan (child centered) dengan menggunakan instrumen hukum yang memayungi hak anak seperti Konvensi Hak Anak (Convention on the Right of the Child) serta Undang-Undang No.23/2002 tentang Perlindungan Anak (Zainal Azikin, 2009).

Dalam pendekatan pembangunan berbasis hak anak, anak ditempatkan dalam konteks yang lebih luas, di mana semua tujuan dari program pembangunan diupayakan untuk memenuhi hak anak secara komprehensif. Prinsip dari pendekatan pembangunan berbasis hak anak ini adalah mempertimbangkan semua kebutuhan anak berdasarkan perkembangan anak; pertanggungjawaban yakni anak-anak memiliki hak dan orang dewasa bertanggung jawab atas hak mereka; kesetaraan yakni non diskriminasi dan inklusif dengan menjamin tidak ada diskriminasi dan mencakup semua anak, baik menurut umur, jenis kelamin, etnis, kemampuan, asal-usul, dan lain-lain; mempromosikan hak dan partisipasi anak untuk berpartisipasi dan didengarkan pendapatnya; selalu mempertimbangkan kepentingan terbaik anak dan bertanggung jawab terhadap anak. Dalam konvensi hak anak, hak asasi anak dikategorikan dalam empat kelompok besar yakni hak hidup, hak tumbuh dan berkembang, hak perlindungan dan hak berpartisipasi, sementara dalam undang-undang perlindungan anak juga mencantumkan hal yang sama dengan menambahkan penghargaan terhadap pendapat anak (Zainal Azikin, 2009).

Dalam pendekatan pembangunan berbasis hak intervensi yang dilakukan untuk mengatasi masalah tidak dilakukan secara parsial atau saling terpisah, tetapi dilakukan secara menyeluruh.Demikian juga dengan para pihak atau stakeholder yang terlibat juga harus menyeluruh dengan tidak mengedepankan ego sektoral. Atau dengan kata lain, semua pihak saling bahu membahu dengan menggunakan semua sumber daya yang dimiliki secara efektif dan efisien. Alasan mendasar mengapa pendekatan pembangunan berbasis hak anak ini digunakan adalah karena anak merupakan generasi penerus yang akan menggantikan generasi saat ini, di tangan anak-anaklah masa depan bangsa kita dipertaruhkan dan dengan memenuhi hak anak sebenarnya kita juga memenuhi hak asasi manusia karena hak anak juga merupakan hak asasi manusia (Zainal Azikin, 2009).

Sektor Pariwisata kadang-kadang dikaitkan dengan hak azasi manusia tetapi jarang dikaitkan dengan isu hak anak walaupun faktanya industri Pariwisata memiliki dampak yang besar terhadap kehidupan anak-anak di seluruh penjuru dunia. Pihak-pihak yang memiliki kewajiban seperti pemerintah atau perusahaanperusahaan Pariwisata memikul tanggung jawab kunci dalam melindungi hak-hak dasar anak, dan jika mereka tidak melindungi hak-hak dasar anak tersebut, maka selalu ada cara agar mereka mau bertanggungjawab (Hidayat, 2010).

Perkembangan pariwisata dapat mempengaruhi kesehatan dan kesejahteraan masyarakat dimana pariwisata tersebut beroperasi. Hal ini berarti bahwa pariwisata dapat secara langsung mempengaruhi anak-anak yang ada dalam komunitas tersebut.Akan tetapi dampak ini bisa berupa positif maupun negatif. Misalnya, walaupun ekonomi berbasis pariwisata yang terus tumbuh dapat membantu memperbaiki kondisi ekonomi dimana anak itu tinggal, akan tetapi hal tersebut juga dapat menghadapkan anakanak pada para pelaku kejahatan seks anak, karena pariwisata yang meningkat pesat dapat membuka akses bagi para wisatawan kaya untuk mengunjungi lokasilokasi, dimana anak-anak dan keluarga miskin berada (Hidayat, 2010). 
Dampak pariwisata terhadap masyarakat, dapat menyoroti hubungan antar perkembangan pariwisata dengan pentingnya mekanisme-mekanisme perlindungan anak di daerah tujuan wisata.Pemerintah dan sektor swasta memiliki kewajiban hukum dan kewajiban moral untuk menjamin bahwa perlindungan anak benar-benar dimasukkan ke dalam agenda pembangunan pariwisata. Tanpa ini, pariwisata tidak bisa menjadi sebuah kekuatan demi kebaikan dalam kehidupan anak-anak dan para wisatawan yang memiliki niat busuk atau jahat akan terus mengeksploitasi anak-anak secara seksual dengan kemakluman.

Hak Azasi Anak dikategorikan dalam empat kelompok yakni hak hidup, hak tumbuh dan berkembang, hak perlindungan, dan hak berpartisipasi, serta penghargaan terhadap pendapat anak.Dalam pendekatan Pembangunan Berbasis Hak Anak, setiap issu yang berkaitan dengan tidak terpenuhinya hak anak dikategorikan sebagai pelanggaran hak anak (Zainal Azikin, 2009).

Alasan mendasar mengapa Pendekatan Pembangunan Berbasis Hak Anak ini digunakan karena anak merupakan generasi penerus, ditangan anak-anak masa depan bangsa kita dipertaruhkan. Dengan memenuhi hak anak, sebenarnya kita juga memenuhi hak azasi manusia karena hak anak juga merupakan hak azasi manusia (Zainal Azikin, 2009).

Penanggulangan adalah upaya yang dilaksanakan untuk mencegah, menghadapi, atau mengatasi suatu keadaan (Aminah Azis, 1998).

Kebijakan penanggulangan kejahatan dapat dilakukan melalui dua pendekatan, yaitu pendekatan penal (penerapan hukum pidana) dan pendekatan non penal (pendekatan di luar hukum pidana).Disimpulkan dalam Kongres ke-5 PBB bahwa berbagai aspek dari kebijakan penanggulangan kejahatan harus dikoordinasikan dan secara keseluruhan harus terintegrasi dalam kebijakan sosial pada setiap Negara (Kartini Kartono, 2005).

\section{METODE}

Metode penelitian yang digunakan adalah metode Studi Kasus yang dilatarbelakangi oleh banyaknya kasus korban Eksploitasi Seksual Komersial pada anak-anak yang belum terungkap khususnya dalam lingkungan Wisata Provinsi Sulawesi Utara. Kasus korban Eksploitasi Seks Komersial di Indonesia pada umumnya (fenomena gunung es ), sehingga menjadi bahan yang utama untuk diangkat sebagai bagian dari upaya untuk mengungkap, merumuskan pendekatan yang tepat dalam upaya menanggulangi anak korban Eksploitasi Seks Komersial baik local, nasional, maupun internasional. Studi ini dirancang dalam jenis atau bentuk Deskriptif kualitatifanalisis yaitu berupaya menganalisis, mengungkap dan menjelaskan ke publik mengenai permasalahan yang dihadapi oleh anak-anak yang menjadi korban eksploitasi seksual komersial anak, yang diharapkan dapat menggugah kesadaran dari pihak-pihak yang prihatin dan bertanggungjawab, untuk menggunakan setiap data dan informasi tersebut dalam upaya mengambil langkah yang tepat. Publik juga perlu digugah kesadarannya bahwa, untuk tumbuh dan berkembang, anak-anak diberi kesempatan untuk bermain, belajar, berinteraksi secara alami dengan teman-temannya dan mengekspresikan potensi yang ada pada dirinya.Dengan demikian orang dewasa, individu maupun kelompok harus memberi ruang yang optimal untuk anak-anak tersebut. Pendekatan Deskriptif ini digunakan dengan alasan bahwa kondisi mengenai anak-anak yang menjadi korban Eksploitasi seksual Komersial memang harus diungkap apa adanya ke permukaan, bukan untuk menyalahkan siapa-siapa sekalipun ada pihak yang bertanggung jawab, namun yang diperlukan adalah dapat menimbulkan kesadaran dari pihak-pihak yang bertanggung-jawab dan prihatin.

Penelitian dengan jenis deskriptif dalam kaitannya dengan korban eksploitasi Seksual Anak di lingkungan wisata Kota Manado Provinsi Sulawesi Utara, sesuai dengan konsep dan aliran pemikiran post-positivist yang lebih menekankan pada penjelasan interpretatif dan pemaknaan terhadap gejala social yang relevan.

Lokasi penelitiannya adalah di lingkungan Wisata Provinsi Sulawesi Utara yang terdiri: Kota Manado, Kotamobagu, Bolaang Mongondow, Kota Bitung, Minahasa Utara, Minahasa Selatan.Informan dalam penelitian merupakan sumber data utama dan mereka ini dibagi dalam dua jenis informan yaitu informan ahli adalah pihak-pihak terkait yang dapat memberikan Informasi data terdiri dari: (1) Pihak Kepolisian, (2) Aktivis LSM seperti LPA dan organisasi HAM/ perempuan di daerah tersebut, (3) Pendamping lapangan seperti pekerja sosial, staf medis, aktivis HIV/AIDS, (4) Penduduk dan Aparat Pemerintah setempat, (5) Tokoh Masyarakat, (6) Tokoh Agama, (7) Pengelola industri wisata, (8) Mucikari/Germo. Sedangkan informan biasa adalah korban eksploitasi seksual komersial.Penentuan sample bagi informan dilakukan secara Opportunistik sampling, dimana peneliti memanfaatkan pertemuan secara insidensial pada saat melakukan kunjungan ke lokasi penelitian. Mengingat bahwa kelompok anakanak yang menjadi korban Eksploitasi Seksual sulit ditemui dan dikunjungi.Pengambilan sampel juga dilakukan secara Snowball Sampling, dimana pemilihan informan dimulai dari satu partisipan, partisipan yang telah diperoleh datanya, diminta pendapatnya untuk melibatkan orang lain atau temannya yang mungkin tertarik atau bersedia menjadi partisipan.

Data Primer Adalah data asli yang dikumpulkan untuk keperluan penelitian yang diperoleh melalui observasi langsung, melakukan pengamatan terlibat, wawancara mendalam dengan informan penelitian, dan Diskusi Kelompok terarah.

Data Sekunder Adalah data yang diperoleh melalui telaah kepustakaan terutama studi-studi terkait misalnya hasil-hasil penelitian yang bertajuk kekerasan seksual pada anak dan literatur-literatur lainnya yang diperlukan dalam perampungan penulisan penelitian.

Peneliti mengadakan observasi yang tidak terstruktur yang harus dilakukan kapan saja, dan dapat dilakukan pada waktu dan tempat tertentu mengingat kondisi korban kekerasan seksual 
anak sangat sulit untuk ditemui dan dikunjungi, disebabkan oleh faktor internal dan struktural seperti: penolakan korban sendiri, manipulasi dari si pelaku, keluarga yang mengalami kasus menganggap bahwa kekerasan seksual terhadap anak merupakan aib yang memalukan jika diungkap secara umum.

Dalam hal ini peneliti tinggal di lokasi penelitian selama waktu tertentu, hidup dan berpartisipasi dalam kegiatan-kegiatan rutin di lokasi penelitian.Keterlibatan peneliti dalam kegiatan sehari-hari yang dilakukan oleh informan penelitian menjadikan terciptanya rapport, yang merupakan prasyarat penting dalam penelitian ini. Peneliti tidak akan mendapatkan informasi yang valid jika tidak tercipta hubungan saling mempercayai. Hubungan tidak harus mendalam, yang terpenting adalah terjadi arus bebas dan keterusterangan dalam komunikasi informasi yang berlangsung dengan informan penelitian, tanpa kecurigaan dan upaya untuk saling menutup diri. Saling mengenal dengan baik dijalin dan terpenting adalah menerima peneliti sebagai bagian dari hidupnya sehingga tidak ada lagi kesenjangan antara peneliti dan para informan penelitian.

Peneliti melakukan pengamatan terlibat, hal ini peneliti menggunakan 2 tehnik wawancara yakni wawancara terstruktur dilakukan kepada informan ahli dalam hal ini : (1) Petugas Kepolisian, (2) LSM setempat seperti LPA (3) Organisasi HAM/Organisasi perempuan (4) Pendamping lapangan seperti pekerja sosial (5) Staf Medis/aktifis HIV AIDS (6). Pihak Pengelola Industri Pariwisata,(7) Tokoh Masyarakat (8) Tokoh Agama (9) aparat setempat.

Wawancara tidak terstruktur, dilakukan kepada informan biasa yakni korban eksploitasi seks komersial anak, Mucikari/ Germo, dan penduduk setempat dimaksudkan agar informan penelitian tidak merasa segan dalam menjawab pertanyaan.Ada jaminan bahwa setiap informan tidak saling mengetahui jawaban atas pertanyaan yang diajukan, maka dari itu peneliti tidak terhambat dalam memperoleh informasi yang dibutuhkan. Untuk menjaga rahasia pribadi, seluruh nama yang disebutkan adalah nama samaran. Dalam wawancara juga diungkap identitas informan, latar belakang keluarga dan pergaulan di sekolah, serta lingkungan sosial masyarakat sekitarnya.

Setelah selesai tahap pra lapangan dan lapangan, peneliti melihat perlunya mengadakan diskusi kelompok terarah atau Focus Group Discussion (FGD) untuk lebih menfokuskan dan menggali informasi yang lebih mendalam tentang akses yang diperlukan korban agar hak-haknya dapat terpenuhi serta upaya penanggulangan korban eksploitasi seksual komersial anak dapat tercapai.

Diskusi kelompok terarah dalam penelitian ini diikuti oleh informan penelitian dalam hal ini korban eksploitasi seksual komersial anak, alasannya adalah informan yang terlibat memiliki karakteristik yang berbeda dalam masalah keterbukaan dan ketertutupan jawaban, yang terlihat pada waktu wawancara mendalam. Dengan diskusi ini diharapkan akan terjadi keterbukaan dan kejelasan jawaban terhadap masalah yang pada waktu wawancara mendalam informan tertutup. Bagi informan yang sudah bersikap terbuka, dalam diskusi diharapkan muncul kejujuran dan kejelasan atas jawaban yang diberikan.Untuk mengikuti diskusi kelompok terarah dibutuhkan pemahaman lebih awal mengenai data-data pendukung yang berkaitan dengan penelitian.

Analisa data dilakukan dengan tiga langkah yakni pengolahan data, reduksi data, penyajian dan pembuatan kesimpulan/generalisasi berdasarkan temuan-temuan kasus. Selain itu peneliti juga akan menggunakan analisis Triangulasi yaitu analisis atas situasi keadaan sosial, ekonomi, budaya informan secara check dan rechek dari berbagai sumber serta meninjau tentang penegakan aturan dan hukum yang berlaku pada wilayah tersebut.

\section{HASIL DAN PEMBAHASAN}

Berdasarkan hasil penelusuran pada berbagai Kota dan Kabupaten di Provinsi Sulawesi Utara, antara lain Kota Manado, Kota Bitung, Kabupaten Bolaang Mongondow, Kabupaten Minahasa Utara, dan Kabupaten Minahasa Selatan, ditemui ada 4 bentuk Eksploitasi Seks Komersial Anak, antara lain :

\section{Prostitusi Anak}

Provinsi Sulawesi Utara yang ber-Ibu Kota kan Manado, merupakan daerah yang telah menjadi daerah asal, daerah transit, dan daerah tujuan untuk perdagangan seks. Kota Manado oleh para pendatang luar selalu memberikan tanggapan dan kesan bahwa daerah ini memiliki ciri khas dan keunikan yang membuat setiap pendatang merasa kagum, sebab orang-orang Manado memiliki sifat yang sangat bersahabat dan terbuka.Namun dibalik itu pula banyak para pendatang yang datang ke Manado hanya untuk kepentingan berwisata seks. Secara kasat mata kita dapat melihat pergaulan kaum remaja menjelang malam sampai dini hari yang sudah sangat memprihatinkan.Banyak sarana hiburan Pub, Discotec, Karaoke di Manado telah memicu para remaja untuk menikmati sarana hiburan tersebut. Bahkan banyak pula oknum-oknum tertentu yang memanfaatkan usia anak-anak dan remaja untuk dirayu dan dibujuk serta diajak masuk kedalam lingkungan orang dewasa yang dapat mengubah pola fikir anak dan remaja berubah kearah yang sebenarnya masih belum layak.

Kota Manado tidak memiliki lokalisasi Pekerja Seks Komersial seperti “Gang Dolly" di Surabaya,tidak ada tempat penampungan khusus atau rumah yang menyediakan jasa layanan tersebut. Semuanya harus di Eksekusi di Hotel, singkatnya harus ada perantara atau orang dalam membimbing untuk mendapat servis ekstra, sehingga orang yang baru pertama kali datang ke Manado dijamin pasti akan mengalami kesulitan untuk langsung mendapatkannya. Paling mudah para Tambio (Tampang Biongo alias sebutan bagi Pekerja Seks Komersial Manado) dicari di Boulevard, merupakan jalan utama Manado di pinggir pantai yang merupakan tempat nongkrong anak muda.

Kondisi tersebut, mendapat pengakuan dari hasil 
wawancara dengan seorang mucikari "Tambio" yang enggan disebut namanya, mengatakan bahwa biasanya kami mucikari menggunakan mobil dan didalamnya ada tiga sampai empat Pekerja Seks Komersial anak persis Showroom berjalan. Para tamu tinggal berjalan pelan menyusuri Jalan Boulevard, lalu kami menawarkan dan kemudian memperlihatkan isi Showroom mobil tersebut, dan bila cocok maka transaksi berlanjut. Tarifnya beraneka macam dari Rp. 300.000,- hingga Rp. 1.000.000,- untuk kencan Short Time. Selanjutnya keterangan lain peneliti peroleh berdasarkan hasil wawancara dengan salah seorang Germo Pria Kemayu, Menuturkan bahwa dia memiliki stok wanita kelas atas yang tarif kencannya seharga 1,5 juta hingga 2,5 juta. dan terbuka menyatakan bahwa dia menikmati keuntungan dari anak buahnya sebesar 15-20 persen per tiap kali kencan dengan tamu hidung belang, Sang Germo Pria kemayu ini mengaku tidak kesulitan mendapatkan tamu-tamu eksklusif, untuk anak-anak buahnya, dia peroleh karena sering nongkrong di tempatnya. Karena menurutnya " Banyak sekali perempuan cantik di sini yang Frustrasi karena ditinggal suami, ada karena kesuciannya oleh pacar yang tak bertanggung jawab,dan sudah terlanjur menganut pergaulan tidak jelas, Ucapnya. "Daripada susah-susah berhubungan dengan Lekong (pria tidak jelas), mending dikomersilkan saja".

Kasus serupa, peneliti temukan berdasarkan hasil penelusuran di Kabupaten Minahasa Utara, tepatnya di Desa Airmadidi, seorang gadis belia bernama Lusy (usia 16 tahun), yang mengaku tidak sempat menyelesaikan pendidikannya di bangku SD ini harus rela dinikahkan oleh kedua orang tuanya dengan laki-laki pilihan orang tuanya, bukan semata-mata pernikahan tanpa alasan melainkan kedua orang tuanya yang tidak mempunyai sebidang tanah untuk tempat tinggal, sehingga dipinjami tanah milik saudara suaminya. Setelah menikah, suaminya justru meninggalkan dirinya tanpa memberikan nafkah lahiriah maupun Batiniah. Proses pertukaran anak perempuan, dengan menikahkannya di usia muda justru memberikan beban tersendiri bagi sang anak. Predikat janda muda yang disandangnya, menyebabkan dia merasa tidak nyaman untuk hidup dalam lingkungan daerah asalnya.Sehingga pilihan untuk keluai pekerjaan mencarifi pekerjaan di luar daerahnya merupakan sebuah alternatif

Prostitusi anak di Kota manado, kian merebak, Hasil penelusuran peneliti, menemukan adanya tempattempat tertentu yang juga diindikasikan sebagai tempat pertemuan sekaligus tempat transaksi seks, Lokasi ini berada di wilayah Malalayang Kota Manado dan disinyalir sebagai tempat esek-esek berkelas hotel Melati paling meriah di Kota ini. Selain itu diketemukan pula ada sebuah tempat di pojokan sebuah Mall sebagai tempat favorit, teraman dan terasyik untuk transaksi bisnis esekesk di Kota manado. Pada ujungnya di tempat penelitian sempat bertemu dengan korban Eksploitasi Seks Komersial anak, lebih Trend disebut sebagai "Ayam Putih abu-abu". Mereka adalah 3 siswi cantik pelajar di sebuah SMK ternama di Kota Manado, beliau berkisah bahwa dalam seminggunya mereka sampai melayani 5 tamu ujar salah seorang diantaranya, selanjutnya dikisahkan bahwa untuk mencari pelanggan, modusnya cukup nongkrong di tempat pusat perbelanjaan dan mal, lengkap dengan pakaian seragam mereka agar calon pelanggan yakin bahwa mereka masih pelajar, mereka duduk di café-café dan bersikap centil untuk menarik perhatian. Menurutnya ada code tertentu yang telah menjadi isyarat diantara mereka.Para lelaki hidung belang yang juga sering datang ke café-café tersebut untuk mencari mangsa sudah paham dengan isyarat terselubung ini.Pada awalnya berkenalan, lalu mentraktir pesanan si pelajar setelah itu calon pelanggan pergi dengan meninggalkan sejumlah uang untuk membayar pesanan makanan dan minuman. Pada saat berpisah itulah terjadi tawar-menawar terjadi lewat sms. Jika harga setuju, pelanggan akan menunggu di kamar hotel. Selanjutnya dijelaskan bahwa soal harga, biasanya mereka mematok harga Rp.1 juta untuk sekali main, dimana pelanggan membayar semua pesanan makan dan minum, taksi menuju hotel dan kamar hotel. Tak jarang mereka mengaku harus melayani pelanggan saat jam sekolah, pilihan membolos pun harus dijalani. Kalaupun melayani diluar jam sekolah, biasanya tidak sampai larut malam dan batas normal hingga jam 7 malam, kisahnya.

Salah satu kategori Pekerja Seks Komersial Anak di Manado adalah Gadis Taxi, penyebutan itu dilatarbelakangi oleh aktifitas Pekerja Seks Komersial ini menggunakan Taxi yang menjemput mereka di tempat kos atau di rumah, sedang Taxi itu tinggal menunggu di lokasi tertentu yang memang telah ditentukan oleh si Pekerja Seks Komersial tersebut.Berdasarkan hasil penelusuran diketahui bahwa si Pekerja Seks Komersial ini terlebih dahulu angkutan umum dari kediamannya , kemudian akan berhenti pada suatu titik tertentu, di mana tidak jauh dari situ Taxi telah terparkir. Untuk menghilangkan kecurigaan, aksi sang gadis dilakukan pada siang hari."Biar tidak menimbulkan kesan negatif dari orang lain" tuturnya.

Korban Eksploitasi Seks Komersial anak ini, sebut saja namanya Chyntia (Usia 18 tahun), pekerjaan ini dilakoni demi memenuhi kebutuhan hidup seharihari, biaya kost dan sekolah.Sebetulnya ada kiriman dari orang tua tetapi tidak mencukupi "tuturnya sembari mengungkapkan kalau dirinya telah menjalani profesi itu selama setahun. Menurutnya orang tuanya tidak pernah mengetahui prihal pekerjaan yang dijalani selama ini dan dirinya pun telah bertekad akan menghapus seluruh jejak petualangnya tersebut pada waktunya. "Saya sudah berjanji, jika kelak menemukan pendamping yang tepat dan mampu menerima dirinya sebagaimana adanya, maka kebiasaan ini akan saya kubur sedalam-dalamnya "paparnya.Menurutnya ada beberapa jasa layanan Taxi yang telah menjadi langganan tetapnya termasuk si supir menjadi pengawas, menjaga keamanan dirinya dari hal-hal yang mungkin saja terjadi dan membahayakan keselamatan dirinya, pungkasnya polos.Lanjut berkisah, bahwa Chyntia tidak ingin membahayakan kesehatan dirinya, untuk itu kemanapun kakinya melangkah, dan masuk arena, dia selalu membawa pengaman."Saya selalu membawa pengaman demi menjaga-jaga sebab ada tamu tertentu yang memang sengaja tidak membawa pengaman. Dan bila sang tamu tidak mau menggunakan 
pengaman, maka saya pun akan segera bergegas pergi" Ungkapnya lirih sembari mengulum senyum lembutnya dan sesekali melirik jam tangannya yang melingkar manis pada kulitnya yang putih mulus pertanda sebentar lagi dia akan berlalu meninggalkan peneliti yang masih asyik menyimak aksi petualangannya di dunia hitam.

Hasil penelusuran peneliti di Kota Bitung Provinsi Sulawesi Utara, Kota Bitung memiliki potensi Eco Tourism yang khas, dan sangat potensial bagi pengembangan Pariwisata seperti Cagar alam dan wisata pantai, maka tidaklah mengherankan bila jumlah Pekerja Seks Komersial di Kota Bitung tiap tahun mengalami peningkatan yang drastis. Praktek Pekerja Seks Komersial di Kota ini adalah Pelacuran terbuka yang legal.

Berdasarkan hasil pengakuan salah seorang informan yang merupakan korban Eksploitasi Seks Komersial Anak dan berstatus sebagai siswi SMP di kota Bitung Provinsi Sulawesi Utara, mengisahkan bahwa di sekolahnya terdapat kawan-kawan yang juga terlibat dalam bisnis pelacuran, dan ada sekitar 17 orang siswi yang sudah biasa berkencan dengan pria dewasa, orang Asing (Bule), bahkan pria tua Bangka yang berusia mencapai 50 tahun, kisahnya sembari tersenyum manis dan melanjutkan kisahnya. Menurutnya, mereka biasanya melakukan praktek prostitusi pada siang hari antara pukul 3 siang hingga pukul 6 sore, agar supaya orang tua tidak menaruh curiga kepadanya dan tetap menganggap mereka sebagai anak yang rajin ke sekolah, anak rumahan dan penurut dengan nasihat orang tua. Ketika dilakukan wawancara lebih mendalam alasan mengapa terjerat sebagai Pekerja Seks Komersial Anak, dengan nada polos dan tersipu malu, dia menjawab karena dikecewakan sang pacar serta keinginan hidup mewah dengan memiliki Handphone bagus, pakaian mahal, kemudian diawali dengan ajakan teman yang lebih dahulu berprofesi sebagai Pekerja Seks Komersial Anak.

Hasil penelusuran peneliti di Kota Bitung Provinsi Sulawesi Utara, kami menemukan modus baru dalam bisnis seks ini, yakni pulang sekolah tidak langsung pulang kerumah, tetapi dibawa ke hotel atau Cottage-Cottage Bule di Kepulauan Lembeh yang jarak tempuh sekitar 30 menit dari Kota Bitung. Demi meyakinkan orang tua, teman-temannya ikut meminta izin dengan dalih mengajak renang atau jalan-jalan, sehingga orang tua tidak menaruh curiga.

Mengenai bayaran sesuai hasil wawancara dengan 6 orang siswa korban Eksploitasi Seks Komersial Anak yang telah menjalani profesi ini selama 6 bulan, menurutnya sangat Variatif, dijelaskan bahwa tarif untuk "Pecah Perawan" berkisar 3 sampai 5 juta, kalau pelakunya itu adalah orang asing, biasanya tarifnya lebih tinggi, kilah salah seorang diantaranya yang mengaku senang Making Love dengan Bule karena merasa diperlakukan sama dengan istri sendiri ketika berkencan dan terkadang dihargai dengan uang Dollar. Kalau Kencan singkat (Short Time), tarifnya sekitar Rp.500.000,- hingga 800.000,- bahkan terkadang hingga Rp.1.000.000,- per kali kencan. Cara pembayarannya boleh secara langsung ataupun dititip melalui teman.

\section{Perdagangan Anak Untuk Tujuan Prostitusi (Trafficing )}

Secara khusus Kota Manado Provinsi Sulawesi Utara merupakan daerah yang telah menjadi daerah asal, daerah transit dan daerah tujuan untuk perdagangan seks. Kota Manado oleh para pendatang luar selalu memberikan tanggapan dan kesan bahwa daerah ini memiliki ciri khas dan keunikan yang membuat setiap pendatang merasa kagum, Sebab Kota Manado memiliki sifat yang sangat bersahabat dan terbuka.

Pada tahun 2004, Provinsi Sulawesi Utara mengeluarkan Peraturan Daerah Provinsi Sulawesi Utara Nomor I tahun 2004 tentang pencegahan dan pemberantasan perdagangan manusia (Trafficing) terutama perempuan dan anak. Sehubungan dengan perdagangan anak, Pasal 23 Peraturan Daerah Provinsi Sulawesi Utara Nomor I tahun 2004 tentang Pencegahan dan Pemberantasan Perdagangan Manusia (Trafficing) terutama perempuan dan anak yang menyatakan bahwa: Korban/ saksi kasus Trafficing berhak berhak mendapatkan perlindungan kerahasiaan diri, identitas, dan keluarganya, tempat tinggal dan tempat kerja dari suatu publikasi untuk tidak disebarkan pada khalayak umum termasuk petugas berwenang, pers maupun terdakwa.

Berdasarkan hasil wawancara dengan bapak Kapolsek Malalayang Kota Manado, menjelaskan bahwa Kejahatan perdagangan anak merupakan fenomena "Gunung Es" karena tidak semua korban/orang tua korban berani untuk melapor. Bahkan ada yang tidak percaya dengan Polisi atau malu keadaan anaknya diketahui oleh orang lain, selanjutnya dijelaskan bahwa dari hasil pemeriksaan termasuk Visum kasus-kasus, terungkap adanya perlakuan salah terhadap korban seperti pelanggaran administrasi seperti pemalsuan KTP, nama, alamat, nama orang tua, umur, dan kasus-kasus Pidana lainnya seperti: kasus pemaksaan, penipuan, penyekapan, pembiusan dalam perjalanan, tidak dibayar gaji, dikurung, disiram air dingin, sodomi, dipaksa melayani lelaki, melayani prilaku seks menyimpang sampai dibunuh secara licik, bahkan ada yang mengidap penyakit HIV/AIDS. Korban sanagt bervariasi mulai dari anak dibawah umur, anak cacat, perempuan dewasa, kebanyakan diperangkap dengan hutang.Ada yang betulbetul hutang dan ada juga hutang buatan yang dibuat oleh pelaku kejahatan atau dijebak dengan menawarkan barang atau pinjaman uang.

Berdasarkan hasil wawancara dengan salah seorang Mucikari yang kini sedang mendekam di balik Jeruji besi Lembaga Pemasyarakatan Sumompo Kota Manado, terpidana 5 tahun 3 bulan penjara karena terpidana kasus Trafficing anak. Sebut saja namanya Benny (26 tahun), Ketika peneliti bertanya asal muasal mengapa Benny terjerat hingga ke Lembaga Pemasyarakatan Sumompo, awalnya ragu-ragu untuk mengungkapkan. Namun ketika diberikan alasan bahwa hal ini positif khususnya bagi gadis-gadis belia Kota Manado, dan Sulawesi Utara pada umumnya agar tidak terjebak di dunia malam menyesatkan itu, Akhirnya Benny memberanikan dirinya untuk berkisah, sebagai berikut: Diungkapkan Benny yang masih berusia 26 tahun ini, bahwa pada awalnya terjun di bisnis pelacuran Kota Manado karena luasnya pergaulan laki-laki yang 
mengaku tinggal di Tuminting ini. "Saya banyak berteman dengan anak-anak Gaul di Kota Manado, Pada mulanya tidak senagaja, ketika ada teman cewek yang masih ABG menawarkan diri untuk para om-om dengan harga yang lumayan, yakni bervariasi dari harga Rp.1 juta hingga Rp. 1,5 juta, dari transaksi itu saya dapatkan beberapa persen dari teman gadis ABG itu" ungkapnya sembari tak merinci berapa yang didapatkan sekali transaksi. "Saya terjun ke bisnis jual perempuan ini sejak tahun 2011, gadis yang sering menggunakan jasanya ada 10 orang, dengan nama samara atau nama gaul, yakni Cia,Nindi, Lave, Merlin, dan Inka. Mereka rata-rata masih sekolah di SMA dan SMK, dan berumur belasan tahun".Menurut Benny, ke sepuluh gadis ABG itu, sudah tidak tinggal lagi dengan orang tua mereka, atau sudah lari dari rumah dan memilih tinggal di Kost.Hal itu dilakukan agar mereka lebih leluasa kesana-kemari atau mencari uang dengan gampangnya dengan menjual diri,"waktu diperiksa Polisi hingga didakwa ke Jaksa Penuntut Umum, saya mengakui semuanya" kisahnya. Peneliti lalu bertanya, mengenai lelaki hidung belang yang sering menggunakan jasanya itu? Benny dengan suara lantang menjawab bahwa pelanggannya semua orang yang mempunyai uang yang banyak, dan rata-rata mereka (lelaki hidung belang,red), punya usaha sampai punya jabatan di Pemerintahan. Harga 1,5 juta itu Short Time atau sekali main, harga itu diluar harga hotel. Malah ada pengusaha turunan China yang sering memakai salah satu gadis ABG saya, rela membooking hingga jutaan rupiah dengan mengajak main diluar daerah seperti Bali dan Jakarta, dan biasanya dibawa selama seminggu. Saya pun dikasih pakai mobilnya, kalau si pengusaha itu lagi keluar daerah dengan ABG kesenangannya, “ jelas Benny sambil menyambung kisahnya, bahwa para lelaki hidung belang tersebut sering menelpon langsung dengan menyebutkan panggilan akrab Benny yang sering dipanggil para ABG-nya dengan sebutan "Papi". Mereka (ABG PSK-red) memanggil saya "Papi", dan para pelanggan yang menelpon saya juga memanggil hal yang sama. Tidak semua pelanggan saya iyakan, karena takutnya kalau itu aparat Polisi, karena sebelum saya ditangkap sudah masuk daftarpencarian orang (DPO) Polres Manado, “ Ungkapnya lagi. Gadis ABG yang ikut sama Benny, merupakan gadis yang rata-rata berusia 16 tahun hingga 18 tahun. Benny selanjur berkisah bahwa " Berakhir petualangan saya ketika salah seorang ABG yang dibawa ke Jakarta tidak pulang-pulang. Ternyata mobil yang dikasih pakai sementara merupakan mobil sewaan. Pas, pemilik mobil melapor ke Polisi, dan mendapatkan mobil tersebut, saya langsung ikut diperiksa .Hal itu terjadi sekitar Maret 2012, Disitu awal saya ditangkap dan dihubungkan dengan laporan dua orang tua ABG ke Polisi. Ternyata tepat dengan data-data yang saya miliki, jadinya saya langsung diproses hokum dan divonis dengan Pasal Undang-Undang Trafficing dan Perlindungan Anak, lalu saya divonis dengan hukuman 5 Tahun 3 bulan hukuman penjara, “ Jelas Onal.

Hasil penelusuran lanjut peneliti lakukan hingga di Kelurahan Amurang, Kabupaten Minahasa Selatan, Berdasarkan hasil wawancara peneliti dengan Bapak Kapolsek Amurang, bahwa di Minahasa
Selatan ini, Mucikari Pekerja Seks Komersial terkenal dan banyak korbannya adalah yang bernama Wensy, tersangka adalah oknum penyewa gadis-gadis belia kepada para hidung belang dan tak terhitung dengan jari lagi. Lanjut menurut Bapak Kapolsek Amurang, korban Eksploitasi Seks Komersial Anak ini kami bawa putar-putar di Minahasa Selatan untuk menunjukkan mana-mana saja kantor tempat si Hidung Belang, lalu dia tunjukkan , makanya kami tahu tempatnya," Tandasnya. Lanjut Bapak Kapolsek itu berkisah sambil sesekali dia mengisap cerutu sambil mengeluarkan gumpalan asap hitamnya, menyatakan bahwa "Kami baru turun di satu sekolah untuk mengambil keterangan korban. Korban ini kami ketahui dari keterangan sang Mucikari Wensy, hasilnya baru satu sekolah itu saja sudah terdapat 12 atau belasan oranglah dan semua jaringan dari si Wensy" ungkapnya. Selanjutnya dia menmbahkan bahwa," besok kami akan turun lagi di Sekolahsekolah untuk mencari keterangan korban lainnya agar jaringan ini bisa terbongkar dan siapa lagi tersangka yang dapat diketahui," Pungkasnya. Menurutnya, korban yang disewakan oleh sang Germo Wensy ini adalah dari beberapa lapisan masyarakat, ada yang Pegawai Negeri Sipil (PNS), pekerja swasta, dan bahkan ada pula diantaranya sebagai anggota Kepolisian. Selanjutnya dikatakan bahwa Kalau di Minahasa Selatan berdasarkan pengakuan korban Eksploitasi Seks Komersial Anak adalah rata-rata penyewanya adalah Pegawai Negeri Sipil (PNS) dari berbagai golongan. Yang sudah kami ketahui pasti, seorang di Dinas Kehutanan, dan seorang lagi sebagai Mantan pejabat Kecamatan di Minahasa selatan, Pejabat BUMN Minahasa Selatan, dan lainnya adalah karyawan swasta dan anggota Kepolisian," Pungkasnya dengan enggan menyebutkan kedua nama Pelaku Pengguna Jasa korban Eksploitasi Seks Komersial Anak. Berdasarkan penjelasan lebih lanjut dari bapak Kapolsek Amurang, berdasarkan pengakuan korban Eksploitasi Seks Komersial pada dirinya, bahwa terdapat 6 lokasi / penginapan dan Hotel yang sering digunakan pelaku dalam melampiaskan hasrat seksualnya kepada korban, antara lain : Penginapan Transit Sinonsayang, Hotel Minahasa Indah di Amurang, Penginapan disamping Pegadaian Amurang, Penginapan MCM yang terletak di jalan menuju Pineleng, rumah Wensy, dan rumah penyewa itu sendiri.

Pertemuan yang lain dalam Wilayah yang sama yakni Kabupaten Minahasa Selatan, peneliti melakukan wawancara mendalam dengan salah seorang korban Eksploitasi Seks Komersial Anak, sebut saja nama Bella (Usia 18 tahun), anak buah sang Mucikari Wensy mengisahkan, bahwa dirinya tak sempat berhubungan seks dengan Mantan Pejabat Kecamatan Minahasa Selatan itu, namun karena dia berlaku kasar, sehingga Bella pun lari meninggalkan sang pejabat sendirian di kamar hotel. Meski demikian, Bella mengaku dirinya sudah sempat dipegang karena sudah disewakan oleh Wensy, demikian penjelasannya. 
Hasil penelusuran selanjutnya, diketemukan kasus di awal bulan Mei 2014 di Kota Mobagu Provinsi Sulawesi Utara, berdasarkan hasil wawancara dengan salahseorang staf Kepolisian di Kota Mobagu, menjelaskan bahwa kasus penjualan anak berusia 13 tahun yang sebelumnya telah diperkosa dan dijual kepada beberapa orang pelanggan, Preman tersebut telah memaksa sang anak untuk melayani para tamu. Namun alhasil sang anak berhasil melarikan diri, sang Preman itu berhasil ditangkap dan mendapatkan hukuman dengan tuduhan pemerkosaan dan kasus Trafficing anak.

Kasus Perdagangan anak lainnya, peneliti berhasil melakukan wawancara mendalam dengan salah seorang korban perdagangan anak, sebut saja namanya Sinta Karina (Umur 17 Tahun), Berasal dari Keluarahan Airmadidi Minahasa Utara Sulawesi Utara, dan mengaku sudah tidak lagi bersatatus sebagai pelajar karena keterbatasan ekonomi, berkisah kalau dirinya pernah dipekerjakan di Bar Blue Diamond Jayapura, dengan janji palsu dari Mucikari bahwa akan dipekerjakan di Jayapura dengan gaji tinggi dan kehidupan senang, termasuk akan menerima uang panjar sebesar Rp.2.000.000,- (Dua Juta Rupiah), dan katanya uang tersebut akan ditinggalkan kepada orang tuanya, namun sesampainya disana, ternyata Sinta dipekerjakan sebagai pelayan nafsu seks dari lelaki hidung belang. Namun pada akhirnya berhasil dipulangkan oleh Pemerintah Jayapura, setelah sekuat tenaga dia melarikan diri dari tangan sang Germo dan pengelola Bar Blue Diamond.

Dari berbagai kasus Perdagangan anak diatas khususnya perempuan dan anak, memperlihatkan kondisi yang sudah sangat memprihatinkan, oleh karena modus penjaringannya berkembang seiring dengan canggihnya kejahatan tersebut dalam melakukan tipu daya terhadap korban .selain sifat kejahatan yang illegal, tersembunyi dan terorganisir dengan rapi baik secara loka, nasional maupun internasional disebabkan oleh beberapa factor pemicu antara lain: kemiskinan, desakan kuat untuk bergaya hidup materialistik, rendahnya tingkat pendidikan, serta terdapat oknum petugas Kelurahan dan Kecamatan yang membantu melakukan pemalsuan KTP.

Menurut hemat Peneliti, Sindikat perdagangan anak untuk tujuan seksual baik yang terjadi di hotelhotel maupun tempat hiburan lain sudah semestinya ditindak dengan keras. Eksploitasi Seks Komersial Anak ini, tidak mempunyai korelasi langsung dengan pengembangan Pariwisata Nasional. Implementasi Undang-Undang Kepariwisataan Nomor 9 Tahun 1990, harus lebih tegas dan konsekwen menolak segala bentuk perjudian dan perzinahan (Wisata Seks), Sebab kondisi saat ini, sekalipun aturan baku itu telah ada, namun kenyataannya, jaringan kerja Pariwisata telah banyak disalahgunakan oleh pihak-pihak tertentu untuk menyelenggarakan bisnis Eksploitasi Seks Komersial Anak, Misalnya Hotel-hotel, tempat hiburan malam, dan pusat relaksasi. Dimana Prostitusi anak yang paling marak mendominasi Provinsi Sulawesi Utara khususnya dan Indonesia pada umumnya dimana turis ataupun pelancong sebagai salah satu pengguna bisnis Eksploitasi Seks Komersial anak.
Hasil penelitian, menghasilkan data bahwa Bagi para Germo (Mucikari), bisnis Prostitusi anak adalah sebuah ladang uang yang sangat menggiurkan, para Germo tidak keberatan mengeluarkan uang dalam jumlah besar demi investasi di bidang ini. Dalam bisnis ini, seorang Germo tidak mengenal rugi sebab konsumen (para lelaki hidung belang), datang sendiri atau langsung menghubunginya . Bagi para Germo, dalam bisnis ini yang terpenting adalah keahlian dalam mencari dan menyediakan pelacurpelacur muda, cantik, bahenol, serta menarik birahi lelaki.

\section{Transformasi Budaya Dan Agama}

Adalah salah satu bentuk Eksploitasi Seks Komersial Anak yang sangat menarik bagi peneliti serta di ketemukan pada Provinsi Sulawesi Utara tepatnya di Kota Bitung, yang sekaligus menjadi pembeda antara bentuk Eksploitasi Seks Komersial Anak di Provinsi lain, dimana sebelumnya peneliti telah melakukan kajian akademis/Riset yang relevan dengan Kekerasan seksual anak dan perempuan.

Bitung merupakan salah kota di Indonesia yang memiliki potensi Eco-Tourism yang khas dan sangat potensial bagi pengembangan sector Pariwisata seperti Cagar Alam dan Wisata Pantai. Hal ini semakin mengundang niat dari para wisatawan asing dan loka untuk melakukan kunjungan wisata ke Kota Bitung Provinsi Sulawesi Utara. Sehingga tidak mengherankan bila jumlah Pekerja Seks Komersial di kota ini dari tahun ke tahun selalu mengalami peningkatan yang drastis.

Hasil penelusuran peneliti, terlihat bahwa kehidupan masyarakat Bitung menunjukkan pola hidup yang mirip dengan masyarakat Barat, dari cara berpakaian hingga pola pergaulan, hal ini dibenarkan oleh hasil wawancara dengan salah seorang penduduk setempat yang berprofesi sebagai tukang jahit di Kota Bitung, beliau menjelaskan bahwa "pakaian yang laris disini adalah modelnya tergantung di Negara Barat, sambil dia memperlihatkan salah satu model pakaian yang baru saja dirampungkannya dan menurutnya sangat digandrungi oleh masyarakat Kota Bitung, terutama kaum muda yakni Celana Model Sapi, yakni celana ketat dan pendek", Pungkasnya

Selain Westernisasi Budaya, Kasus Transformasi Agama dengan motif Penganten Pesanan biasa dilakukan oleh para turis Asing dari berbagai negara, Pacaran ( Hamilisasi ), dan Bantuan Sosial juga mendominasi Kota Bitung ini. Hal ini sesuai dengan hasil wawancara dengan salah seorang tokoh agama di Kota Bitung, menjelaskan bahwa, ada beberapa keluarga yang memiliki gadis umur belasan pernah didekati oleh beberapa pelaku dengan motifBantuan social dengan iming-iming kehidupan akan lebih sejahtera, agar supaya keluarga tersebut merelakan anaknya untuk dinikahi dan lambat laun menarik keluarga tersebut untuk masuk kedalam golongannya ( Agama tertentu ), Alhasil ada yang berlanjut hingga dibawa ke Negara sang pelaku, dan adapula yang ditinggalkan begitu saja dalam keadaan hamil dan punya anak setelah ijin kontrak usaha sang pelaku telah berakhir. Begitupun dengan kebanyakan para remaja telah menjadi korban akhirnya meninggalkan agama yang selama ini telah dianutnya setelah melalui proses "Pacaran" dan di hamili oleh sang Pelaku yang kebanyakan Wisatan Asing. 


\section{Pornografi Dan Pornoaksi Anak}

Pornografi adalah pertunjukan apapun atau dengan cara apa saja yang melibatkan anak dalam aktifitas seksual yang nyata atau eksplisit atau yang menampilkan bagian tubuh anak demi tujuan seksual. (Konvensi Hak Anak, Pasal 2 dan 3).

Kasus pelecehan seksual di Kota Manado Sulawesi Utara, mengalami peningkatan. Terbukti dengan banyaknya kasus pelecehan seksual pada korban, yang umumnya di dominasi oleh anak dibawah umur atau wanita remaja. Berdasarkan hasil wawancara dengan salah seorang staf Unit Perlindungan Perempuan dan Anak (PPA) Polresta Manado, menjelaskan bahwa jumlah kasus pelecehan seksual anak yang terdata setiap bulannya, adalah kurang lebih 35 kasus. Khusus tahun 2013, dari 350-an kasus, yang masuk tahap 1 dan 2 ada 60 kasus, yang mencabut laporan ada sekitar 165 pelapor, yang dilimpahkan ada 8 kasus dan yang di SP3 kan ada 30 kasus, dan yang masih merupakan tunggakan kasus sekitar 80-an kasus," Sebagian besar kasus berakhir dengan perdamaian, alasannya karena sudah ada kesepakatan antara pelapor maupun terlapor.Pemicu pelecehan seksual umumnya karena kebiasaan menonton film porno dan lemahnya pengawasan orang tua terhadap prilaku anaknya terutama diluar rumah. Pungkasnya.

Kasus lainnya berhasil diidentifikasi berdasarkan hasil wawancara dengan dua orang korban atas nama Linda (12 tahun) dan Melly (13 tahun), dengan pelaku seorang oknum Pegawai Negeri Sipil, berinisial Edward (30 tahun) di Kauditan. Pelaku saat ini diproses oleh Polres Minahasa Utara.

Penelusuran selanjutnya terkait kasus ini, teridentifikasi adanya kasus Video Porno yang melibatkan pasangan pelajar di salah satu sekolah Menengah Tingkat Atas Kota Manado. Berdasarkan hasil wawancara dengan pihak Dinas Pendidikan pada saat peneliti berkunjung ke tempatnya, menyatakan bahwa kalau timnya baru saja kembali dari sekolah bersangkutan dan ternyata benar ada kasus Video Porno itu dan barang buktinya telah disita oleh sang guru. Sedangkan barang bukti lainnya yang telah beredar di ponsel-ponsel beberapa siswa, langsung dihapus oleh siswa lainnya karena takut diketahui," Paparnya, dijelaskannya, sekembali dari sekolah tersebut, pihaknya langsung menugaskan guru Pembina sekolah itu untuk menyelidiki secara detail permasalahan kejadian maupun beredarnya Video Porno yang berdurasi antara 5 menit yang berlokasi di tempat kost siswa tersebut. Selain prihatin terjadinya kasus tersebut, pihk kami turut menyesalkan tindakan dari pihak sekolah yang langsung memberhentikan kedua siswa bersangkutan tanpa di koordinasikan terlebih dahulu dengan Dinas Pendidikan .Sebab dengan telah dikeluarkannya kedua siswa, justru membuat pihak Dinas Pendidikan kesulitan mendapatkan informasi dan penjelasan dari korban, termasuk penyelidikan mengapa perbuatan maksiat itu sampai bisa terjadi.“ Tandasnya.

Kasus serupa berhasil diidentifikasi di Kota Bitung pada salah satu Keluarahan di Kecamatan Maesa, Berdasarkan hasil wawancara dengan bapak Kapolsek Kota Bitung, menjelaskan bahwa pelaku Video Mesum telah beredar luas di tengah masyarakat Kota Bitung.
Pelakunya adalah sepasang kekasih bernama Hendry (19) sebagai sang actor dan Lely (16) tahun sang aktris warga yang berasal dari salah satu Kelurahan di Kecamatan Maesa. Di hadapan Penyidik Kasus, Hendry mengakui semua perbuatannya bahwa dia sebagai pelaku dalam Video yang berdurasi 2 menit dan direkam dengan menggunakan HP, yang direkam sejak 28 April 2013 lalu, dikamar rumah miliknya. Hal yang sama pun diakui oleh Lely, yang mengaku bahwa rekaman itu inisiatif Hendry dan ia sempat meminta agar rekaman tersebut segera dihapus, namun sebelum dihapus rekaman tersebut malah sudah tersebar, sehingga telah diketahui oleh banyak orang termasuk orang tua mereka. "Orang tua marah besar dengan kejadian ini, dan ibu sempat pingsan setelah mengetahu kejadian ini," tutur Lely yang mengaku takut mendapatkan hukuman atas ulah mereka. Mereka juga mengakui telah menjalin cinta sejak lima tahun yang lalu dan sering melakukan hubungan selayaknya suami istri. Namun pengakuannya baru sekali ini merekam aksi tak senonoh ini dengan menggunakan HP. “ Kami juga berencana akan menikah namun karena beda keyakinan dan tidak disetujui oleh kedua orang tua kami“", Ucap Lely. Lanjut dijelaskan oleh Bapak Kapolsek Kota Bitung, tersangka perempuan berinisial Yola (27 tahun), warga Kakenturan I yang dituding oleh kedua pasangan tersebut sebagai penyebar Video Mesumnya dengan menggunakan Bluetooth. Namun Yola membantah tuduhan tersebut, karena diakuinya Video Mesum tersebut didapatkan pada adiknya."Saya tidak mengerti mengapa mereka menuduh saya, padahal video tersebut nanti saya dapatkan setelah beredar luas," tampiknya. Seperti diketahui bahwa dalam video tersebut terlihat seorang perempuan yang memakai kaos berwarna merah yang dibalut sweater berwarna ungu dengan setengah telanjang, sementara sang actor terlihat tak menggunakan busana yang sedang melakukan hubungan layaknya suami istri sambil bergantian merekam. Barang bukti berupa HP dan Videonya telah diamankan.

Kasus serupa berhasil ditelusuri di Kepulauan Lembeh Kota Bitung, sebut saja namanya Nona (16 tahun ) anak perempuan seorang nelayan di Kepulauan Lembeh mengaku bersama dengan seorang kawannya yang berusia 15 tahun di foto telanjang oleh orang Asing/Bule . Nona dibujuk oleh kawannya lalu diajak kesebuah Villa milik orang asing/Bule .setelah difoto, lalu ia dan kawannya diberi uang masing-masing RP.200.000,- (Dua Ratus Ribu Rupiah) per anak.

Kasus serupa, berhasil diidentifikasi di Kota Mobagu, diketemukan "Rekaman Film Porno", yang diambil melalui Handphone telah diedarkan oleh pacarnya sendiri. Ketika peneliti mencoba menemui korban anak Eksploitasi Seksual Komersia tersebut, nampaknya keluarga korban tertutup dan sama sekali tidak merespon kedatangan peneliti sekalipun sebelunya telah diupayakan dengan metode Persuasif. Alhamdulillah, peneliti berhasil menggali informasi dari tetangga korban, menurut penjelasan para tetangga korban, mengatakan kalau anak tersebut telah diungsikan oleh keluarga ke lokasi yang tidak diketahui.

Banyaknya kasus kekerasan seksual anak tersebut diatas, memberikan indikasi bahwa di Provinsi 
Sulawesi Utara pada khususnya, Indikator Perlindungan Anak dari perlakuan salah, kualitasnya masih sangat buruk. Keberadaan anak yang belum mampu untuk hidup mandiri dan tentunya masih sangat membutuhkan orang-orang sebagai tempat berlindung, akan tetapi kenyataannya, anak-anak justru dijadikan sebagai obyek seksualitas, Perdagangan, Pornografi, obata-obatan dan sebagainya.

\section{SIMPULAN}

Berdasarkan hasil penelusuran pada berbagai Kota dan Kabupaten di Provinsi Sulawesi Utara, antara lain Kota Manado, Kota Bitung, Kabupaten Bolaang Mongondow, Kabupaten Minahasa Utara, dan Kabupaten Minahasa Selatan, ditemui ada 4 bentuk Eksploitasi Seks Komersial Anak, antara lain: Prostitusi Anak, khusus di Kota Manado, tidak memiliki lokalisasi pekerja seks komersial, tidak ada tempat penampungan khusus atau rumah yang menyediakan jasa layanan tersebut, semuanya harus di eksekusi di hotel, singkatnya harus ada perantara atau orang dalam membimbing untuk mendapatkan Servis Ekstra; Germo/mucikari. Sampel lain di Kota Bitung diketemukan korban Eksploitasi Seks Komersial anak dari kalangan pelajar yang melakukan praktek prostitusi pada siang hari sekitar pukul 3 siang hingga pukul 6 sore agar orang tua dan keluarga tidak menaruh curiga kepadanya dan tetap menganggap anak rajin ke sekolah. Gadis belia tersebut biasanya dibawa ke Cottage-Cottage Bule di Kepulauan Lembeh yang jarak tempuh 30 menit dari kota Bitung.

\section{DAFTAR PUSTAKA}

Azikin, Z. 2009, Pendekatan Pembangunan Berbasis Hak Anak. Kupang: Suara Nusa Tenggara Timur.

Azis, A. 1998. Aspek Hukum Perlindungan Anak. Medan: USU Press.

Dinas Sosial, 2004. Data Pelacuran Anak di Jawa Barat. Bandung: Dinas Sosial Jawa Barat.

Erwin. 2011, Eksploitasi Seks Komersial Anak Di Indonesia. Jakarta: KOMNAS PESKA-ECPAT.

Hidayat, R. 2010. Implikasi Korban Kekerasan Seksual Di Perkampungan Nelayan Sulawesi-Selatan. Jurnal Aktualita ISSN No.2085-3505 Volume III Edisi ke-4 Agustus 2011/ Kantor KOPERTIS Wil IX, Sulawesi.

Irwanto, 2001. Perdagangan Anak Di Indonesia. Yogyakarta: Pustaka Pelajar.

Irwanto, 2008. Menentang Pornografi dan Eksploitasi Seks Komersial Anak. Jakarta: ECPAT.

Kartono Kartini( 2005 ), Patologi Sosial dan Kenakalan Remaja. Jakarta: Rajawali Pers.

Undang-undang No. 23 Tahun 2002. Tentang Pelindungan Anak.

Undang-undang No. 91 tahun 990. Tentang Kepariwisataan 